\title{
Obituary
}

\section{DAVID MAELGWYN JOSLIN (1925-1970)}

The death of David Joslin, on 15 October 1970, came as a great shock to his many friends and colleagues throughout the world, and it has deprived Latin American studies here and abroad not only of a distinguished scholar but also of a warm and sympathetic personality. He was only forty-five, and while he leaves behind a high reputation as teacher, writer and editor, there can be no doubt that his future contribution to the development of Latin American studies in general, and to economic history in particular, would have been outstanding. In mourning his loss, we are conscious both of achievements already recorded and of promise unfulfilled.

David Joslin was educated at Barry County School, Glamorgan, and at St John's College, Cambridge, where he took First Class Honours in Part One of the history tripos in 1947, and again in Part Two in 1948. This was after an undergraduate career interrupted by war service in the Royal Naval Volunteer Reserve. After graduation, he was elected Strathcona Student at St John's, and in 195I to a fellowship at Pembroke College, where he remained until his death. He had a brilliant professional career: in 1952, at the early age of twenty-seven, he became director of studies in history at his college, and Senior Tutor as well in 1962. Elected to an assistant lectureship in the university in 1954, and to a full lectureship soon afterwards, he was appointed Professor of Economic History in 1965 , serving also on both the Council of the Senate and the General Board of the Faculties.

Outstanding as a teacher and administrator alike, David Joslin also made a distinctive reputation as an editor, being associated with The Economic History Review, the modern volumes of the Cambridge Economic History, and the Ellen McArthur Studies in Economic History. As an author, he contributed to several volumes of collected studies, but it was the appearance, in 1963, of his book $A$ Century of Banking in Latin America which stamped David Joslin as an authority on the economic history of the continent. The preparation of this book gave its author opportunities of travel and research, during which he formed many valuable friendships abroad and acquired a remarkable knowledge of the sources of his chosen field. 


\section{Obituary}

We shall not now see the economic history of Latin America on which David Joslin was working when he died, but we can record, with gratitude, his contribution to the growth of Latin American studies in Britain. At the time of his death he was chairman of the Centre for Latin American Studies at Cambridge, co-editor of the Cambridge University Press's Latin American Studies series, and co-editor of this Journal. To these, and, indeed, to all he undertook, David Joslin brought a fine intelligence, acute perception, a distinctive sense of humour, and a warmth of personality, and no one who had been his pupil, his colleague or his friend could fail to admire his rare combination of qualities. The loss we have suffered by his death will be deeply felt, and not least by this Journal which he helped to found and to which he contributed so much. 